\title{
Faktor Risiko Prediktor Bakteremia pada Pasien Nekrolisis Epidermal: Evidence-Based Case Report
}

\author{
Shafira Anindya, Parikesit Muhammad, Windy Keumala Budianti \\ Departemen Dermatologi dan Venereologi, Fakultas Kedokteran Universitas Indonesia, \\ RSUPN dr. Cipto Mangunkusumo, Jakarta, Indonesia \\ Alamat Korespondensi: shafiraanindya@gmail.com
}

\begin{abstract}
Abstrak
Nekrolisis epidermal (NE) yang terbagi atas Sindrom Stevens-Johnson (SSJ) dan nekrolisis epidermal toksik (NET) merupakan reaksi simpang obat berat dengan mortalitas tinggi. Penyebab kematian terbanyak pada NE adalah sepsis, namun gejala sepsis tidak spesifik pada NE dan hasil kultur darah membutuhkan waktu lama. Oleh karena itu penting mengetahui prediktor yang berpengaruh terhadap peningkatan risiko bakteremia pada pasien dengan NE. Evidence-based case report ini bertujuan mengetahui faktor prediktor terjadinya bakteremia pada pasien NE berdasarkan literatur. Pencarian artikel menggunakan basis data PubMed, Cochrane, dan Scopus yang relevan dengan pertanyaan klinis untuk kemudian ditelaah. Didapatkan dua artikel kohort yang sesuai. Studi Koh dkk. mendapatkan tiga prediktor yang berpengaruh terhadap kejadian bakteremia pada pasien NE; yaitu hemoglobin $\leq 10 \mathrm{~g} / \mathrm{dL}$ (odds ratio [OR] 2,4; interval kepercayaan [IK] 95\% 2,2-2,6), luas epidermolisis $\geq 10 \%$ (OR 14,3; IK 95\% 13,4-15,2) dan penyakit komorbid kardiovaskular (OR 2,1; IK 95\% 2,0-2,3). Studi De Prost dkk. mendapatkan tiga prediktor yaitu usia > 40 tahun (hazard ratio [HR] 2,5; IK 95\% 1,35-4,63), leukosit > 10.000/ $\mathrm{mm}^{3}$ (HR 1,9; IK 95\% 0,96-3,61), serta LPB $\geq 30 \%$ (HR 2,5; IK 95\% 1,13-5,47). Epidermolisis yang lebih luas merupakan faktor prediktor terjadinya bakteremia pada NE di kedua studi. Faktor risiko lainnya memerlukan penelitian lebih lanjut.
\end{abstract}

Kata Kunci: bakteremia, nekrolisis epidermal, prediktor

\section{Bacteremia Risk Factor Predictor in Epidermal Necrolysis: An Evidence-Based Case Report}

\begin{abstract}
Epidermal necrolysis (EN) that consist of Stevens-Johnson Syndrome (SJS) and Toxic Epidermal Necrolisis (TEN) is severe drug reaction with high mortality. Although the major cause of death in EN is sepsis, its symptoms in SJS is unspecific and blood culture takes a long time to get result. Thus, it is important to understand the predictor for risk of bacteremia in EN. This evidence-based case report aims to discover the predictive factors for bacteremia in EN based on current literatures. We searched for articles relevant with the clinical question using databases from PubMed, Cochrane, and Scopus. Two relevant cohort articles were critically appraised. Three predictors were determined in Koh et al. including haemoglobin $\leq 10 \mathrm{~g} / \mathrm{dL}$ (odds ratio [OR] 2,4); confidence level (CL) 95\% 2,2-2,6, body surface area (BSA) $\geq 10 \%$, (OR 14,3; CL 95\% 13,415,2) and cardiovascular disease (OR 2,1; CL 95\% 2,0-2,3). In De Prost et al. three predictors were also found including age > 40 years (hazard ratio [HR] 2,5; CL 95\% 1,35-4,63), leukocyte > 10.000/ $\mathrm{mm}^{3}$ (HR 1,9; CL 95\% 0,96-3,61), and BSA $\geq 30 \%$. (HR 2,5; ICL95\% 1,13-5,47). Thus, higher BSA is a common predictor for bacteremia in SJS. Further studies for other risk factors are needed.
\end{abstract}

Keywords: bacteremia, epidermal necrolysis, predictor 


\section{Pendahuluan}

Nekrolisis epidermal (NE) yang terdiri atas Sindrom Stevens-Johnson (SSJ) dan nekrolisis epidermal toksik (NET) merupakan reaksi simpang obat berat yang ditandai dengan lepasnya epidermis dan mukositis. ${ }^{1}$ Kategori SSJ dan NET dibedakan berdasarkan luas permukaan badan (LPB) yang mengalami epidermolisis. Apabila epidermolisis < 10\% LPB dikategorikan SSJ, 10$30 \%$ LPB dikategorikan overlap SSJ-NET, dan > $30 \%$ LPB dikategorikan NET.

Beberapa teori mengenai patofisiologi SSJ dan NET saat ini semakin berkembang. ${ }^{2}$ Keduanya merupakan reaksi hipersensitivitas yang dimediasi oleh sistem imun yang telah dilaporkan terjadi terhadap setidaknya 200 macam obat. ${ }^{3}$ Obat penyebab tersering adalah obat antiinflamasi nonsteroid (OAINS), ${ }^{4,5}$ golongan sulfa,,${ }^{6,7}$ antibiotik laktam, antikonvulsan (misalnya karbamazepin, fenobarbital, dan fenitoin), antiretrovirus, agen kontras, alopurinol, dan lainlain. ${ }^{8,9}$ Kerusakan jaringan pada NE terjadi akibat apoptosis sel keratinosit yang diinduksi oleh stimulus stres, kerusakan DNA, dan sitokin intraselular. ${ }^{2,3}$

Insidens terjadinya SSJ diperkirakan 1-6,5 kasus per juta orang per tahun. ${ }^{10,11}$ Angka kematian pada NE bervariasi dari mulai $10 \%$ untuk SSJ hingga $50 \%$ untuk NET. ${ }^{12}$ Data dari ruang rawat inap RSUPN Dr. Cipto Mangunkusumo Jakarta (RSCM) yang merupakan rumah sakit rujukan nasional di Indonesia menunjukkan bahwa selama tahun 2010-2013 terdapat 57 kasus NE dengan rincian: SSJ 47,4\%, overlap SSJ-NET 19,3\%, NET $33,3 \%$, dengan angka kematian total $10,5 \%$. Penelitian Mahri dkk (2018) di RSCM pada tahun 2014-2017 terdapat 34 kasus NE dengan angka kematian pada SSJ $18,2 \%$, overlap SSJ-NET $14,3 \%$, dan NET $14,3 \% .{ }^{13}$ Penelitian Suwarsa dkk (2016) di RS Hasan Sadikin Bandung tahun 20092013 menunjukkan sejumlah 57 pasien NE dengan 7 kasus kematian $(12,28 \%)$ dan 5 dari 7 kematian

\section{Skenario Kasus}

Seorang laki-laki 65 tahun, datang ke IGD dengan keluhan kulit kemerahan, lepuh, dan luka pada seluruh tubuh, termasuk mata dan rongga mulut, disertai demam yang memburuk sejak 1 hari yang lalu. Dua minggu yang lalu, pasien mendapatkan obat alopurinol untuk nyeri sendi akibat penyakit gout dari Puskesmas. Setelah 14 hari mengonsumsi obat tersebut, muncul kemerahan pada kulit, sehingga pasien berobat ke Puskesmas. Di Puskesmas, pasien dinyatakan mengalami alergi obat sehingga obat tersebut tersebut disebabkan oleh sepsis. ${ }^{14}$

Beberapa studi mengidentifikasi hubungan kejadian SSJ dan NET dengan infeksi virus, misalnya human immunodeficiency virus (HIV), ${ }^{15}$ Epstein-Barr virus (EBV), ${ }^{16}$ influenza virus, ${ }^{17}$ cytomegalovirus (CMV), herpes simplex virus (HSV), ${ }^{17}$ dan coxsackievirus. ${ }^{18}$ Meskipun infeksi virus lebih sering mencetuskan SSJ dan NET, infeksi bakteri (misalnya Streptococcus sp. dan Meningococcus sp.) juga dilaporkan dapat menginduksi SSJ dan NET. ${ }^{3}$ Hsu dkk (2016) melaporkan pasien dengan septikemia atau infeksi bakteri apapun, lebih sering mengalami SSJ dan NET dengan odds ratio (OR) 4,1 dan 2,56. ${ }^{19}$

Untuk menentukan risiko mortalitas pada pasien dengan nekrolisis epidermal, digunakan skoring prognostik SCORTEN yang dibuat oleh Batsuji-Garin dkk (2000) yang memberikan skor 1 untuk beberapa hal berikut: usia $>40$ tahun, denyut jantung >120/menit, terdapat kanker atau keganasan hematologik, epidermolisis > 10\% LPB, kadar urea serum $>10 \mathrm{mM} / \mathrm{L}(28 \mathrm{mg} / \mathrm{dL})$, kadar bikarbonat serum $<20 \mathrm{mEq} / \mathrm{L}$, dan kadar gula darah sewaktu > $14 \mathrm{mM} / \mathrm{L}(252 \mathrm{mg} / \mathrm{dL})$. Angka kematian pasien NE dengan SCORTEN 0-1 sebesar $3,2 \%$, SCORTEN $212,1 \%$, SCORTEN 3 $35,8 \%$, SCORTEN $458,3 \%$, dan SCORTEN 5 $90 \%$.

Penyebab kematian terbanyak pada NE adalah sepsis yang menyebabkan sekitar 50\% kematian, yang terutama terjadi pada fase akut. ${ }^{12}$ Pemberian antibiotik profilaksis tidak direkomendasikan sebelum terdapat konfirmasi bakteremia yang dinilai berdasarkan hasil kultur darah yang positif, atau adanya kecurigaan sepsis. Meskipun demikian, gejala sepsis tidak spesifik pada pasien dengan NE, dan hasil kultur darah membutuhkan waktu yang cukup lama. Oleh karena itu, penulis membuat evidence-based case report (EBCR) untuk mengetahui faktor-faktor risiko yang merupakan prediktor terjadinya bakteremia pada pasien NE.

dihentikan. Namun, gejala yang dialami pasien terus memburuk sehingga pasien kembali berobat ke Puskesmas dan dirujuk untuk dirawat. Pasien didiagnosis NET dengan LPB sebesar 32\%. Pasien tidak memiliki riwayat penyakit kardiovaskular. Ketika pasien dirawat, dokter memeriksakan kultur darah pasien untuk menentukan bakteremia dan mengambil keputusan terkait pemberian antibiotik. Pasien dilakukan pemeriksaan darah dengan hasil hemoglobin $11 \mathrm{~g} / \mathrm{dL}$, leukosit $15.000 / \mathrm{mm}^{3}$. Anak pasien yang merupakan seorang mahasiswa 
kedokteran menanyakan kepada dokter mengenai faktor-faktor yang memengaruhi terjadinya bakteremia pada kasus NET yang dialami ayahnya karena ia baru saja membaca tentang tingginya angka kematian akibat bakteremia. Kemudian, dokter memutuskan untuk melakukan telaah kritis.

\section{Pertanyaan Klinis}

\section{Metodologi}

\section{Strategi Pencarian Artikel}

Dilakukan penelusuran kepustakaan pada tanggal 8 Agustus 2021 dari 3 basis data jurnal, yaitu: Pubmed, Cochrane, dan Scopus. Kata kunci yang digunakan adalah: "Stevens-Johnson syndrome" dan "bacteremia" dengan padanannya, yaitu: ((stevens-johnson syndrome[Title/Abstract]) OR (epidermal necrolysis[Title/Abstract])) AND ((bacteremia[Title/Abstract]) OR (blood stream infection[Title/Abstract])). Penelusuran artikel dibatasi oleh desain studi yaitu: kohort dan telaah sistematis, serta artikel dengan subjek penelitian manusia.

\section{Strategi Seleksi Artikel}

Dilakukan penyaringan judul dan abstrak sesuai dengan kata kunci, dengan eliminasi publikasi
Apakah faktor yang meningkatkan risiko terjadinya bakteremia pada pasien NE?

$\mathrm{P} \quad$ : Pasien etnis melayu berusia 18-60 tahun, dengan nekrolisis epidermal LPB > $10 \%$

$\begin{array}{ll}\text { I } & :- \\ \text { C } & :- \\ \text { O } & \text { : Bakteremia }\end{array}$

ganda. Kemudian artikel dibaca secara utuh untuk memeriksa kesesuaiannya dengan PICO dan kriteria eligibilitas. Telaah kritis dilakukan pada artikel terpilih menggunakan pedoman telaah kritis jenis studi prognosis dari Center of EvidenceBased Medicine, University of Oxford.

Kriteria Eligibilitas

Dalam pencarian literatur, populasi NE tidak dibatasi oleh usia maupun jenis kelamin. Luaran yang akan dinilai adalah kejadian bakteremia, yaitu infeksi pada aliran darah pasien yang ditegakkan dengan kultur darah. Kriteria inklusi dalam EBCR ini adalah kesesuaian dengan pertanyaan klinis, artikel yang berbahasa Inggris, serta menggunakan subjek manusia, sementara kriteria eksklusi adalah desain penelitian selain kohort atau telaah sistematis.

artikel kohort yang sesuai dengan pertanyaan klinis dan kriteria eligibilitas (Gambar 1).
Ditemukan 89 artikel yang sesuai dengan kata kunci. Dari penyaringan artikel didapatkan 2

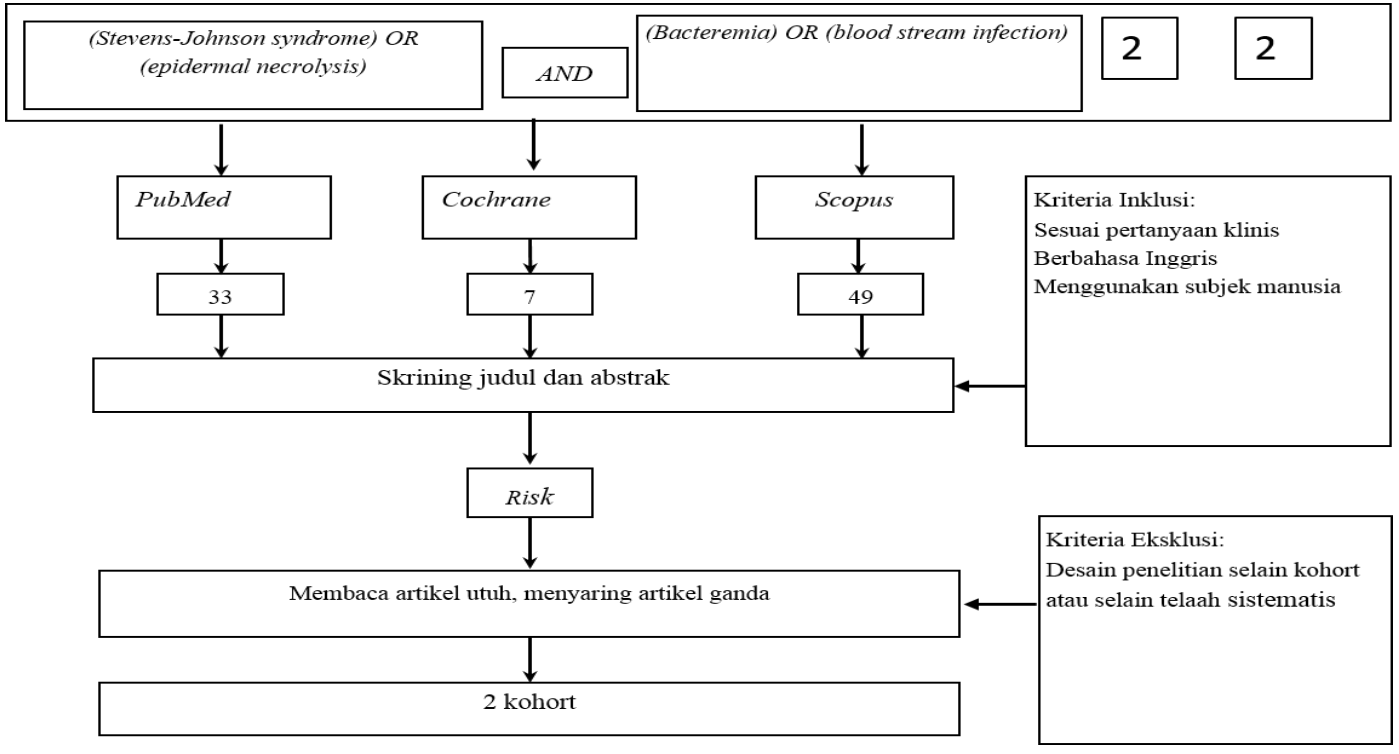

Gambar 1. Bagan Alur Seleksi Artikel (Dilakukan pada 8 Agustus 2021 Pukul 17.00 WIB) 
Berdasarkan hasil penelusuran artikel, terdapat dua artikel yang sesuai, yaitu:

1. De Prost N, Ingen-Housz-Oro S, Duong TA, Valeyrie-Allanore L, Legrand P, Wolkenstein P, et al. Bacteremia in Stevens-Johnson syndrome and toxic epidermal necrolysis: epidemiology, risk factors, and predictive value of skin cultures. Medicine (Baltimore). 2010;89:28-36. ${ }^{21}$

2. Koh HK, Chai ZT, Tay HW, Fook-Chong S, Choo KJL, Oh $\mathrm{CC}$, et al. Risk factors and diagnostic markers of bacteremia in Stevensohnson syndrome and toxic epidermal necrolysis: a cohort study of 176 patients. J Am Acad Dermatol. 2019;81:686-93. ${ }^{22}$ Karakteristik kedua artikel tersebut dapat dilihat pada Tabel 1.

\section{Telaah Kritis}

Telaah kritis dilakukan pada dua artikel yang relevan berdasarkan kriteria validity, importance, dan applicability (Tabel 2).

Tabel 1. Karakteristik Artikel

\begin{tabular}{|c|c|c|c|c|c|}
\hline Artikel & $\begin{array}{c}\text { Tahun } \\
\text { Publikasi }\end{array}$ & $\begin{array}{c}\text { Karakteristik } \\
\text { Subjek }\end{array}$ & Outcome & Kekuatan & Kelemahan \\
\hline $\begin{array}{c}\text { De Prost } \\
\text { dkk }\end{array}$ & 2010 & $\begin{array}{l}\text { Total } 179 \text { pasien, } 78 \\
\text { pasien SSJ }(43,6 \%), \\
68 \text { pasien didiagnosis } \\
\text { overlap SSJ-NET } \\
(38,0 \%) \text {, dan } 33 \\
\text { pasien didiagnosis } \\
\text { NET }(18,4 \%) \text {. } \\
\text { Median usia } 42 \text { tahun } \\
\text { (jangkauan } \\
\text { interkuartil 16-58), } \\
\text { etnis tidak dijelaskan } \\
\text { namun penelitian di } \\
\text { negara Prancis. }\end{array}$ & 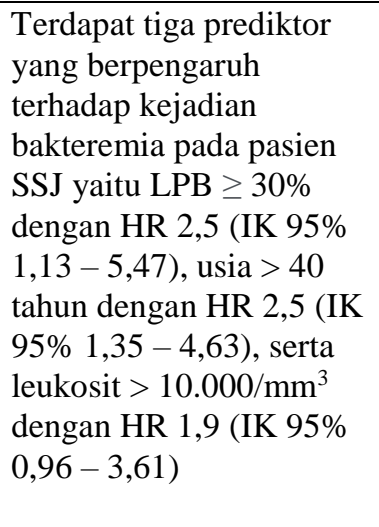 & $\begin{array}{l}\text { Penelitian } \\
\text { kohort } \\
\text { dengan } \\
\text { periode } 11 \\
\text { tahun. }\end{array}$ & $\begin{array}{l}\text { Kohort } \\
\text { retrospektif, } \\
\text { single-center } \\
\text { study. }\end{array}$ \\
\hline Koh dkk & 2019 & $\begin{array}{l}176 \text { pasien, } 59 \text { pasien } \\
\text { didiagnosis SSJ } \\
(33.5 \%), 51 \text { pasien } \\
\text { didiagnosis overlap } \\
\text { SSJ-NET }(29,0 \%) \text {, } \\
\text { dan } 66 \text { pasien } \\
\text { didiagnosis NET } \\
\text { (37,5\%). Median usia } \\
57 \text { (jangkauan } \\
\text { interkuartil } 44-71) \text {, } \\
\text { etnis sebagian besar } \\
\text { China dan Melayu. }\end{array}$ & $\begin{array}{l}\text { Terdapat tiga prediktor } \\
\text { yang berpengaruh } \\
\text { terhadap kejadian } \\
\text { bakteremia pada pasien } \\
\text { SSJ yaitu LPB } \geq 10 \% \\
\text { dengan OR } 14,3 \text { (IK 95\% } \\
\text { 13,4 - 15,2), hemoglobin } \\
\leq 10 \text { g/dL dengan OR 2,4 } \\
\text { dan (IK 95\% 2,2 - 2,6), } \\
\text { serta penyakit } \\
\text { kardiovaskular dengan } \\
\text { OR 2,1 (IK 95\% 2,02- } \\
2,3 \text { ). }\end{array}$ & $\begin{array}{l}\text { Penelitian } \\
\text { kohort } \\
\text { dengan } \\
\text { periode } 14 \\
\text { tahun. }\end{array}$ & $\begin{array}{l}\text { Kohort } \\
\text { retrospektif, } \\
\text { single-center } \\
\text { study. }\end{array}$ \\
\hline
\end{tabular}


Tabel 2. Hasil Telaah Kritis

\begin{tabular}{|c|c|c|}
\hline Kriteria Penilaian & De Prost dkk $(2010)^{21}$ & Koh dkk (2019) ${ }^{22}$ \\
\hline \multicolumn{3}{|l|}{ Validity } \\
\hline Apakah awal & Ya & $\mathbf{Y a}$ \\
\hline penelitian & Pada bagian metode, subjek penelitian & Pada bagian metode, subjek penelitian \\
\hline didefinisikan dengan & terdiri atas 179 pasien nekrolisis epidermal & terdiri atas 176 pasien nekrolisis epidermal \\
\hline jelas dan taat asas, & yang dirawat di rumah sakit tersier di Paris, & yang dirawat di Singapore General \\
\hline misalnya saat & Prancis sejak November 1997 hingga & Hospital, Singapura sejak November 2003 \\
\hline \multirow[t]{4}{*}{ diagnosis ditegakkan? } & Oktober 2008. Semua pasien direkrut & hingga 2016. Semua pasien direkrut ketika \\
\hline & ketika hari pertama masuk rawat inap. & hari pertama masuk rawat inap. Semua \\
\hline & Semua pasien terduga SSJ, overlap SSJ- & pasien terduga SSJ, overlap SSJ-NET, dan \\
\hline & $\begin{array}{l}\text { NET, dan NET didiagnosis dengan } \\
\text { pemeriksaan biopsi kulit. }\end{array}$ & $\begin{array}{l}\text { NET didiagnosis dengan pemeriksaan } \\
\text { biopsi kulit. }\end{array}$ \\
\hline Apakah follow-up & Ya & Ya \\
\hline dilakukan secara & Pengamatan dilakukan terhadap semua & Pengamatan dilakukan terhadap semua \\
\hline memadai? & $\begin{array}{l}\text { subjek sejak masuk perawatan di rumah } \\
\text { sakit hingga pasien meninggal atau pulang. }\end{array}$ & $\begin{array}{l}\text { subjek sejak masuk perawatan di rumah } \\
\text { sakit hingga pasien meninggal atau pulang. }\end{array}$ \\
\hline Apakah luaran dinilai & Ya & Ya \\
\hline dengan kriteria & Luaran berupa bakteremia ditentukan & Luaran berupa bakteremia ditentukan \\
\hline $\begin{array}{l}\text { objektif, bila mungkin } \\
\text { tersamar? }\end{array}$ & dengan pemeriksaan kultur darah. & dengan pemeriksaan kultur darah. \\
\hline Apakah diidentifikasi & Ya & Ya \\
\hline kelompok dengan & Dilakukan analisis regresi Cox multivariat. & Dilakukan analisis regresi Cox multivariat. \\
\hline berbeda? & & \\
\hline Apakah hasil sudah & Tidak & Tidak \\
\hline
\end{tabular}

divalidasi pada

kelompok subjek yang

lain?

Importance

Berapa besar

kemungkinan

terjadinya outcome

dari waktu ke waktu?

Berapa tepatkah

estimasi terjadinya

outcome yang diteliti?

\section{Applicability \\ Apakah pasien kita mirip dengan subjek penelitian? \\ Apakah simpulan kita tentang hasil studi berguna bagi pasien dalam tata laksana secara keseluruhan?}

Kurva Kaplan-Meier probabilitas bebas dari bakteremia atau bloodstream infection (BSI) pada pasien SSJ, overlap SSJ-NET, dan NET pada Gambar 2.

Terdapat tiga prediktor yang berpengaruh terhadap kejadian bakteremia pada pasien SSJ yaitu:

-LPB $\geq 30 \%$ dengan HR 2,5 (IK 95\% 1,13 $-5,47)$.

-Usia > 40 tahun dengan HR 2,5 (IK 95\% $1,35-4,63$ )

-Leukosit > 10.000/. $\mathrm{mm}^{3}$ dengan HR 1,9 (IK $95 \% 0,96-3,61$ )

\section{Ya}

Pasien mengalami nekrolisis epidermal, berusia 65 tahun.

Ya

Pasien memiliki faktor risiko yaitu usia > 40 tahun sehingga meningkatkan risiko kemungkinan terjadinya bakteremia 2,5 kali lipat dibandingkan pasien sindrom Stevens Johnson yang berusia <40 tahun. Kadar leukosit pasien $>10.000 / \mathrm{mm}^{3}$ sehingga meningkatkan risiko bakteremia 1,9 kali lipat. Keterlibatan LPB pada pasien $>30 \%$ sehingga meningkatkan risiko bakteremia 2,5 kali lipat. 


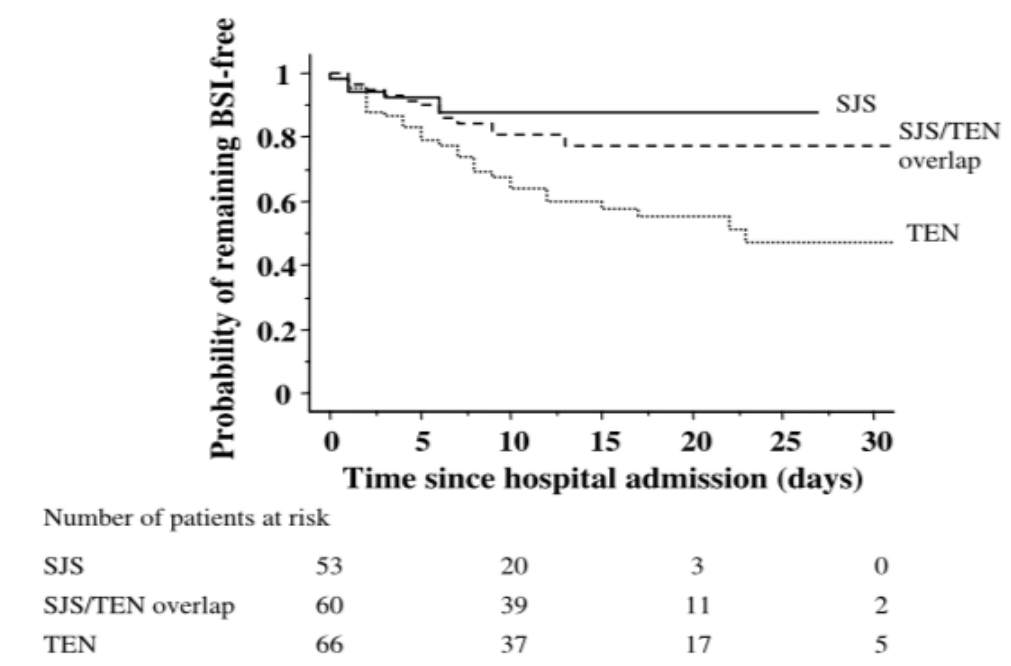

Gambar 2. Kurva Kaplan-Meier Probabilitas Bebas dari Bakteremia atau Bloodstream Infection (BSI) pada Pasien SSJ, Overlap SSJ-NET, dan NET pada Studi De Prost dkk (2010) ${ }^{21}$

\section{Diskusi}

Pada studi De Prost dkk (2010), dari 179 pasien, 78 pasien didiagnosis SSJ $(43,6 \%), 68$ pasien didiagnosis overlap SSJ-NET $(38,0 \%)$, dan 33 pasien didiagnosis NET $(18,4 \%) .{ }^{21}$ Bakteremia terjadi pada 48 pasien $(26,8 \%)$. Median waktu yang dibutuhkan sejak awitan penyakit hingga terjadinya bakteremia adalah 11 hari (jangkauan interkuartil $8-15$ hari), sementara median waktu yang dibutuhkan sejak pasien masuk rawat inap di rumah sakit hingga terjadi bakteremia adalah 5 hari (jangkauan interkuartil 2-9 hari). Median lama perawatan di rumah sakit adalah 22 hari (jangkauan interkuartil 13 - 36 hari) pada pasien dengan bakteremia dan 12 hari (jangkauan interkuartil 8 18 hari) pada pasien lainnya ( $p<0,0001)$. Bakteremia berhubungan dengan mortalitas ketika masa rawat inap dalam analisis multivariat dengan odds ratio (OR) 2,7 dan interval kepercayaan (IK) 95\% 1,12 - 6,59. Angka kematian pasien rawat inap akibat SSJ, overlap SSJ-NET, maupun NET adalah $13,4 \%$.

Pada studi Koh dkk (2019), dari 176 pasien, 59 pasien didiagnosis SSJ (33.5\%), 51 pasien didiagnosis overlap SSJ-NET (29,0\%), dan 66 pasien didiagnosis NET (37,5\%). Median usia 57 (jangkauan interkuartil 44-71). ${ }^{22}$ Bakteremia terjadi pada 52 pasien (29.5\%). Angka kematian pasien rawat inap akibat SSJ, overlap SSJ-NET, maupun NET sebesar $23,9 \%$. Bakteremia pada NE meningkatkan risiko kematian dengan odds ratio (OR) 4,4 dan interval kepercayaan (IK) 95\% 2,1 9,1. Selain itu, pasien NE dengan bakteremia lebih berisiko dan membutuhkan perawatan di ICU (OR
$6,8$ dan $95 \%$ IK $3,1-15,0)$ serta waktu perawatan di rumah sakit yang lebih lama $(\mathrm{p}<0,0005)$ dibandingkan dengan pasien NE tanpa bakteremia. Median waktu yang dibutuhkan sejak onset penyakit hingga terjadinya bakteremia adalah 9 hari.

Studi Koh dkk (2019) dan De Prost dkk (2010) memiliki satu faktor prediktor yang sama yaitu luas epidermolisis permukaan badan yang terlibat. Pada studi De Prost dkk (2010) ditemukan peningkatan risiko bakteremia pada $\mathrm{LPB} \geq 30 \%$ dengan HR 2,5 (IK 95\% 1,13 - 5,47), sementara pada studi Koh dkk (2019) LPB $\geq 10 \%$ dengan OR 14,3 (IK 95\% $13,4-15,2)$. Selain itu didapatkan masing-masing 2 prediktor lain pada kedua studi. Studi Koh dkk (2019) mendapatkan 2 prediktor lain yaitu hemoglobin $\leq 10 \mathrm{~g} / \mathrm{dL}$ dengan OR 2,4 (IK 95\% 2,2 - 2,6), serta penyakit kardiovaskular dengan OR 2,1 (IK 95\% 2,02 - 2,3), sementara studi De Prost dkk (2010), yaitu usia > 40 tahun dengan HR 2,5

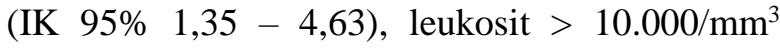
dengan HR 1,9 (IK 95\% 0,96-3,61). ${ }^{21}$

Studi Lipovy dkk (2018) tidak menilai secara spesifik faktor risiko terjadinya bakteremia pada pasien SSJ-NET. ${ }^{23}$ Studi tersebut menilai tiga faktor risiko potensial terjadinya bakteremia yaitu SCORTEN, lama rawat atau length of stay (LOS), serta waktu antara awitan gejala dan rujukan ke unit luka bakar. Terdapat hubungan yang bermakna antara LOS dengan kejadian bakteremia. Akan tetapi hubungan tersebut bersifat dua arah karena pasien dengan bakteremia memerlukan waktu perawatan yang lebih lama. Studi tersebut tidak dapat mengidentifikasi faktor prediktor terjadinya bakteremia pada SSJ-NET. 


\section{Simpulan}

Epidermolisis dengan LPB yang lebih luas merupakan faktor prediktor terjadinya bakteremia pada SSJ. Meskipun demikian, faktor prediktor lainnya masih inkonklusif hingga saat ini dan memerlukan penelitian lebih lanjut.

\section{Daftar Pustaka}

1. Kirchhof MG, Miliszewski MA, Sikora S, Papp A, Dutz JP. Retrospective review of StevensJohnson syndrome/toxic epidermal necrolysis treatment comparing intravenous immunoglobulin with cyclosporine. J Am Acad Dermatol. 2014;71:941-7.

2. Diana R, Rahayu T, Wirawan E, Dhamayanti $\mathrm{M}$, Irawanto $\mathrm{M}$. Pathophysiology and management of Stevens-Johnson syndrome and toxic epidermal necrolysis. J Gen Proced Dermatol Venereol Indones. 2020;5:28-39.

3. Cheng L. Current pharmacogenetic perspective on Stevens-Johnson syndrome and toxic epidermal necrolysis. Front Pharmacol. 2021;12:1-17.

4. Kowalski ML, Asero R, Bavbek S, Blanca M, Blanca-Lopez N, Bochenek G, et al. Classification and practical approach to the diagnosis and management of hypersensitivity to nonsteroidal anti-inflammatory drugs. Allergy Eur $\mathbf{J}$ Allergy Clin Immunol. 2013;68:1219-32.

5. Chong I, Chao A. Stevens-Johnson syndrome/toxic epidermal necrolysis and treatment with a biologic: a case report. Perm J. 2017;21:4-7.

6. Kongpan T, Mahasirimongkol S, Konyoung P, Kanjanawart S, Chumworathayi P, Wichukchinda N, et al. Candidate HLA genes for prediction of co-trimoxazole-induced severe cutaneous reactions. Pharmacogenet Genomics. 2015;25:402-11.

7. Sukasem C, Sririttha S, Tempark T, Klaewsongkram J, Rerkpattanapipat T, Puangpetch A, et al. Genetic and clinical risk factors associated with phenytoin-induced cutaneous adverse drug reactions in Thai population. Pharmacoepidemiol Drug Saf. 2020;29:565-74.

8. Yang Y, Zhang Z, Lu X, Zhu X, Huang Q, Liang $\mathrm{J}$, et al. Occupational toxic epidermal necrolysis associated with dalbergia cochinchinensis: a retrospective comparative study of eight cases in China. Int J Dermatol. 2015;54:1435-41.
9. Zhao J, Hu L, Zhang L, Zhou M, Gao L, Cheng L. Causative drugs for drug-induced cutaneous reactions in central China: a 608-case analysis. An Bras Dermatol. 2019;94:664-70.

10. Mockenhaupt M, Roujeau J. Epidermal necrolysis (Stevens-Johnson syndrome and toxic epidermal necrolysis). In: Kang $S$, Amagai M, Bruckner AL, Enk AH, Margolis DJ, McMichael A, et al., editor. Fitzpatrick's dermatology. McGraw-Hill Education; 2019. hal. 733-48.

11. Chaby G, Maldini C, Haddad C, LebrunVignes B, Hemery F, Ingen-Housz-Oro S, et al. Incidence of and mortality from epidermal necrolysis (Stevens-Johnson syndrome/toxic epidermal necrolysis) in France during 200316: a four-source capture-recapture estimate. Br J Dermatol. 2020;182:618-24.

12. Yamane Y, Matsukura S, Watanabe Y, Yamaguchi Y, Nakamura K, Kambara T, et al. Retrospective analysis of Stevens-Johnson syndrome and toxic epidermal necrolysis in 87 Japanese patients - treatment and outcome. Allergol Int. 2016;65:74-81.

13. Mahri S, Nuary T, Mughni FA, Budianti WK. A four years retrospective study of Stevens Johnson syndrome - toxic epidermal necrolysis treatments in a national tertiary referral hospital. In: Sawitri, Prakoeswa CRS, Ervianti E, Reza NR, Alinda MD, Anggraeni S, editor. 23rd Regional Conference of Dermatology (Asian-Australian) 2018 Incorporating with The 16th Annual Scientific Meeting of the Dermatology and Venerology. Surabaya; 2018. hal. 276.

14. Suwarsa O, Yuwita W, Dharmadji HP, Sutedja E. Stevens-Johnson syndrome and toxic epidermal necrolysis in Dr. Hasan Sadikin General Hospital Bandung, Indonesia from 2009-2013. Asia Pac Allergy. 2016;6:43.

15. Mittmann N, Knowles SR, Koo M, Shear NH, Rachlis A, Rourke SB. Incidence of toxic epidermal necrolysis and Stevens-Johnson syndrome in an HIV cohort. Am J Clin Dermatol. 2012;13:49-54.

16. Brunet-Possenti F, Steff M, Marinho E, Crickx B, Descamps V. Syndrome de StevensJohnson au cours d'une primo-infection par le virus d'Epstein-Barr. Ann Dermatol Venereol. 2013;140:112-5.

17. Lerch M, Mainetti C, Terziroli Beretta-Piccoli B, Harr T. Current perspectives on StevensJohnson syndrome and toxic epidermal necrolysis. Clin Rev Allergy Immunol. 2018;54:147-76. 
18. Chung WH, Shih SR, Chang CF, Lin TY, Huang YC, Chang SC, et al. Clinicopathologic analysis of coxsackievirus A6 new variant induced widespread mucocutaneous bullous reactions mimicking severe cutaneous adverse reactions. J Infect Dis. 2013;208:1968-78.

19. Hsu DY, Brieva J, Silverberg NB, Silverberg JI. Morbidity and mortality of StevensJohnson syndrome and toxic epidermal necrolysis in United States adults. J Invest Dermatol. 2016;136:1387-97.

20. Bastuji-Garin S, Fouchard N, Bertocchi M, Roujeau JC, Revuz J, Wolkenstein P. Scorten: a severity-of-illness score for toxic epidermal necrolysis. J Invest Dermatol. 2000;115:14953.

21. De Prost N, Ingen-Housz-Oro S, Duong TA, Valeyrie-Allanore L, Legrand P, Wolkenstein $\mathrm{P}$, et al. Bacteremia in Stevens-Johnson syndrome and toxic epidermal necrolysis: epidemiology, risk factors, and predictive value of skin cultures. Medicine (Baltimore). 2010;89:28-36.

22. Koh HK, Chai ZT, Tay HW, Fook-Chong S, Choo KJL, Oh CC, et al. Risk factors and diagnostic markers of bacteremia in StevensJohnson syndrome and toxic epidermal necrolysis: a cohort study of 176 patients. J Am Acad Dermatol. 2019;81:686-93.

23. Lipový B, Holoubek J, Hanslianová M, Cvanová M, Klein L, Grossová I, et al. Toxic epidermal necrolysis data from the CELESTE multinational registry. Part II: Specific systemic and local risk factors for the development of infectious complications. Burns. 2018;44:1561-72. 